Ekspansi: Jurnal Ekonomi, Keuangan, Perbankan dan Akuntansi

ISSN (Online): 2580-7668 ISSN (Print): 2085-5230

Vol. 11, No. 1 (Mei 2019), Hal. 77 - 86

\title{
PERSEPSI SIVITAS AKADEMIKA MUSLIM TERHADAP WAKAF UANG
}

\author{
Nurul Huda ${ }^{1}$, Perdana Wahyu Sentosa ${ }^{2}$ Novarini $^{3}$ \\ ${ }^{1,2}$ Universitas YARSI, Jakarta, Indonesia \\ ${ }^{3}$ Sekolah Tinggi Ilmu Ekonomi Muhammadiyah, Jakarta, Indonesia \\ Email Korespondensi: nurul.huda@yarsi.ac.id
}

\begin{abstract}
The low collection of cash waqf is one of them due to the level of public understanding of cash waqf. This research aims to describe the characteristics of respondents based on the socio-economic demography of the Muslim Academic Community; and analyze of factors of influence people's perceptions of cash waqf in the Muslim Academic Community. The research method used is logistic regression analysis. The sample in this study were 138 respondents who were The Muslim Academic Community in Jabodetabek. The results showed that the respondents' characteristics of the sex of most women, aged between 20 years and less than 25 years, had income of less than Rp 3 million per month, were not married, had family members between 3 and 5 people, less than 2 people worked, have family responsibilities, students in university, have not worked, Private Universities in Central Jakarta, and the majority have never doing cash waqf. The results of the logistic regression analysis indicate that a person's level of faith and one's age can significantly influence perceptions of doing cash waqf.
\end{abstract}

Keywords: Perception, Cash Waqf, Muslim Academic Community, Logistic Regression.

Abstrak: Rendahnya penghimpunan wakaf uang salah satunya disebabkan tingkat pemahaman masyarakat mengenai wakaf uang. Penelitian ini bertujuan untuk mendeskripsikan karakteristik responden berdasarkan demografi sosial-ekonomi Sivitas Akademika Muslim; dan menganalis faktor-faktor apa saja yang mempengaruhi persepsi masyarakat terhadap wakaf uang pada Sivitas Akademika Muslim. Metode penelitian yang digunakan adalah analisis regresi logistik. Sampel dalam penelitian ini sebanyak 138 responden merupakan sivitas akademika wilayah jabodetabek. Hasil penelitian menunjukkan bahwa karakteristik responden dari jenis kelamin kebanyakan perempuan, berusia antara 20 tahun sampai kurang dari 25 tahun, memiliki pendapatan kurang dari Rp 3 juta per bulan, belum menikah, memiliki anggota keluarga antara 3 sampai 5 orang, kurang dari 2 orang yang bekerja, memiliki tanggungan keluarga, mahasiswa, belum bekerja, Perguruan Tinggi Swasta di Jakarta Pusat, dan mayoritas belum pernah berwakaf uang. Hasil analisa regresi logistik menunjukkan bahwa variabel tingkat keimanan seseorang dan usia seseorang dapat mempengaruhi persepsi untuk melakukan wakaf uang secara signifikan.

Kata Kunci: Persepsi, Wakaf Uang, Sivitas Akademika Muslim, Regresi logistic.

DOI: $10.35313 /$ ekspansi.v11i1.1328

Riwayat Artikel:

Diterima: $12-2-2019$

Direvisi: 7 - 4 - 2019

Disetujui: 10 - 4-2019 


\section{PENDAHULUAN}

Masyarakat di Indonesia umumnya lebih mengenal istilah wakaf adalah dengan harta benda tidak bergerak seperti masjid atau tanah dan peruntukan wakaf banyak dipergunakan untuk keperluan ibadah, perkuburan, dan pendidikan. Hal ini diperkuat dengan hasil penelitian Pusat Bahasa dan Budaya (PBB) UIN Syarif Hidayatullah Jakarta dalam Dahlan (2014) menunjukkan, bahwa harta wakaf lebih banyak bersifat diam (77\%) daripada yang menghasilkan atau produktif (23\%). Temuan lain menunjukkan, pemanfaatan terbesar harta wakaf adalah masjid (79\%) daripada peruntukan lainnya, dan lebih banyak berada di wilayah pedesaan (59\%) daripada perkotaan (41\%). Hal ini menunjukkan bahwa tanah wakaf yang cukup luas itu belum memberikan manfaat produktif, melainkan sebagian besar masih dipergunakan untuk keperluan konsumtif.

Potensi penghimpunan wakaf uang di Indonesia juga terhitung cukup besar. Berdasarkan perhitungan Nasution dan Hasanah (2005) tentang penghimpunan wakaf uang, jika diasumsikan jumlah penduduk umat muslim di Indonesia yang bersedia berwakaf uang sebanyak 10 juta jiwa dengan asumsi ratarata penghasilan perbulan $\mathrm{Rp}$ 500. 000 hingga Rp 10. 000 000, maka paling tidak akan terkumpul dana sekitar 3 triliun rupiah selama setahun.

Faktanya penghimpunan wakaf uang yang telah dilakukan oleh beberapa lembaga nazhir berskala nasional pun tidak ada yang mencapai angka potensi tersebut. Berdasarkan data Badan Wakaf Indonesia (2016), sebagai lembaga independen yang membawahi wakaf di Indonesia, sejak tahun 2011 sampai tahun 2015 total penghimpunan wakaf uang di seluruh Indonesia baru mencapai Rp 185 milyar dari 52 lembaga nazir wakaf uang yang terdaftar di BWI. Hal tersebut masih sangat jauh dari perhitungan potensi wakaf uang di Indonesia yang bisa mencapai triliunan rupiah pertahunnya. Data Akhir tahun 2017 jumlah wakaf uang yang berhasil dihimpun Rp 199,094,773,196 melalui 69 Nazhir wakaf uang .

Rendahnya penghimpunan wakaf uang, salah satu penyebabnya adalah persepsi pemahaman masyarakat tentang wakaf yang masih sangat terbatas jika dibandingkan dengan pengertian mereka tentang zakat, infak, dan sedekah (Hadayani, Kurnia (2015), Rahmawati (2013). Hal tersebut diperkuat dengan pendapat Hasanah (2009), bahwa salah satu faktor yang menyebabkan wakaf Indonesia belum berperan dalam memberdayakan ekonomi umat adalah masih kurangnya pemahaman masyarakat tentang hukum dan benda yang diwakafkan.

Nizar (2014) melakukan penelitian mengenai Faktor-Faktor yang Mempengaruhi Persepsi Wakif Tentang Wakaf Uang. Metode analisis yang digunakan dalam penelitian ini adalah analisis deskriptif dan analisis regresi logistik. Variabel yang digunakan dalam penelitian ini adalah tingkat pendidikan, tingkat pendapatan, mazhab yang diikuti, dan media informasi. Hasil penelitian ini menunjukkan bahwa variabel pendidikan memiliki peluang yang lebih besar dan signifikan dalam menjelaskan persepsi wakif tentang wakaf uang.

Penelitian ini mengkaji bagaimana karakteristik masyarakat berdasarkan demografi sosial-ekonomi Sivitas Akademika Muslim dan faktor-faktor apa saja yang 
mempengaruhi persepsi masyarakat terhadap wakaf uang pada Sivitas Akademika Muslim.

\section{TINJAUAN PUSTAKA}

Persepsi merupakan suatu proses yang menyangkut masuknya pesan atau informasi ke dalam otak manusia. Melalui persepsi manusia terus-menerus mengadakan hubungan dengan lingkungannya (Sarwono (2010), Slameto (2010)). Hubungan dilakukan yaitu dengan inderanya, yaitu indera pengelihatan, pendengaran, peraba, dan penciuman.

Walgito (2010) mengungkapkan bahwa persepsi merupakan proses akhir dari pengamatan yang diawali oleh proses penginderaan. Proses diterimanya stimulus oleh indera menimbulkan perhatian khusus lalu diteruskan ke otak dan setelah itu individu akan mengerti makna dari stimulus tersebut. Dengan persepsi, individu dapat menyadari tentang keadaan lingkungan disekitarnya maupun hal yang ada dalam diri individu tersebut. Maka dari itu persepsi sedikit banyak akan mempengaruhi bagaimana seseorang berperilaku. Respon sebagai akibat dari persepsi dapat dilakukan individu dalam berbagai macam bentuk perilaku.

Wakaf tunai (cash waqf) pertama kali dipakai pada masa Utsman di Mesir, di akhir abad ke-16 (1555-1823 M) (Cizakca, 2004) Pada era Utsmani di Mesir, berkembang pemakaian fikih Hanafi dalam menjalankan aktivitas binis dan sosialnya. Imam Muhammad asy-Syaibani menjelaskan bahwa sekalipun tidak ada dukungan hadis yang kuat, penggunaan harta bergerak sebagai wakaf dibolehkan, jika memang hal itu sudah menjadi kebiasaan umum pada daerah tertentu. Bahkan bagi Imam Muhammad al Sarakhsi, kebiasaan umum tidak selalu menjadi persyaratan dalam penggunaan harta bergerak sebagai harta wakaf. Bahkan menurut Crecelius, menyatakan: (Daniel, 1995) "No Islamic State was more energetic in its production of statistical records, more systematic in its record keeping, and more assiduous in preserving these records than the Ottoman Empire." Artinya: "Tidak ada negara Islam yang lebih energik dalam menghasilkan wakaf dan catatan statistiknya, lebih sistematis dalam menjaga catatan tersebut, serta lebih ketat dalam mengawasi catatan tersebut ketimbang Dinasti Ustman.”

Abdullah dan Aristoni (2015) wakaf uang merupakan suatu produk baru dalam sejarah perekonomian Islam yang menjadi bagian dari wakaf tunai. Wakaf uang sendiri diartikan sebagai perbuatan hukum Wakif untuk memisahkan dan atau menyerahkan sebagian harta benda miliknya yang berupa uang untuk dimanfaatkan selamanya atau untuk jangka waktu tertentu sesuai dengan kepentingannya guna keperluan ibadah dan atau kesejahteraan umum menurut syariah.

Mochtar, Sidin and Razak (2015) Skema wakaf uang hanyalah instrumen lain dalam perbankan dan keuangan Islam yang membuatnya berbeda dari produk yang ditawarkan dalam perbankan konvensional.

Dahlan (2017) nazhir yang memiliki sedikit informasi tentang wakaf uang sebanyak 0,053 kali dengan yang menyatakan setuju terhadap wakaf uang dibandingkan dengan nazhir yang memiliki banyak informasi. Atau dengan kata lain nazhir yang memiliki banyak informasi sebanyak 9,95 kali dengan yang menyatakan 
setuju terhadap wakaf uang dibandingkan dengan nazhir yang memiliki sedikit informasi.

\section{METODE PENELITIAN}

Penelitian ini menggunakan model logit, yaitu suatu model untuk mengetahui probabilitas terjadinya suatu peristiwa dengan mengikuti fungsi distribusi logistik. Model logit memiliki variabel dependen berupa data kualitatif yang sudah dikategorikan menggunakan variabel dummy, sesuai definisi operasional yang digunakan.

Regresi logistik dalam penelitian ini digunakan untuk menganalisis peluang kejadian masyarakat untuk berwakaf dengan model sebagai berikut:

\section{$\operatorname{Ln}(\mathrm{p} / 1-\mathrm{p})=\boldsymbol{\alpha} 0+\boldsymbol{\alpha} 1 \operatorname{Iman}_{\mathrm{i}}+\boldsymbol{\alpha} 2$ Didik $_{\mathrm{i}}+\boldsymbol{\alpha} 3$ Pendpt $_{\mathrm{i}}+\boldsymbol{\alpha} 4$ Tanggungan $_{\mathrm{i}}+\boldsymbol{\alpha} 5$ Norma $_{\mathrm{i}}$ $+\alpha 6$ Info $_{i}+\alpha 7$ Org $_{i}+\alpha 8$ Usia $_{i+}+\alpha 9$ Paham $_{i}+\varepsilon_{i}$}

\section{Dimana:}

$\mathrm{p} / 1-\mathrm{p} \quad$ : persepsi responden terhadap wakaf uang (bernilai 1 untuk "menerima wakaf uang" dan 0 untuk "menolak wakaf uang")

Iman : total skor variabel keimanan seorang responden

Didik : lama pendidikan formal seorang responden

Pendp : jumlah pendapatan yang diterima setiap bulan (rupiah)

Tanggungan : jumlah tanggungan dalam keluarga (orang)

Norma : total skor variabel keyakinan normatif seorang responden

Info : total skor variabel akses media informasi

Org : keaktifan dalam berorganisasi sosial keagamaan

(bernilai 1 untuk responden yang aktif, 2 untuk responden yang kurang aktif, dan 3 untuk responden yang tidak aktif)

Usia : usia responden (tahun)

Paham : total skor variabel pemahaman responden mengenai wakaf uang

$\varepsilon \quad$ : galat atau error $\mathrm{i}$

: responden ke-i $(\mathrm{i}=1,2,3, . ., \mathrm{n})$

Model dalam penelitian ini terdiri dari 5 variabel independen maka jumlah sampel yang dibutuhkan adalah antara 50-125 sampel. Berpedoman pada Hair dkk (1995) (dalam Ferdinand, 2005) maka sampel yang disarankan adalah berkisar 100-200. Sampel yang diambil merupakan sivitas Akademika Muslim Jakarta Pusat dan Timur. Pada penelitian ini sampel berjumlah 138

\section{HASIL DAN PEMBAHASAN}

Beberapa variabel dalam penelitian ini berupa variabel iman, norma, info, dan pemahaman mengenai wakaf uang menggunakan instrument kuesioner dengan skala likert. Hasil uji validitas dan realibilitas semua variabel dalam penelitian ini adalah valid dan andal.

Deskripsi statistik mengenai usia responden menunjukkan bahwa paling banyak responden berusia antara 20 tahun sampai kurang dari 25 tahun. Hal ini berkaitan dengan target responden dalam penelitian ini adalah mahasiswa. Mahasiswa dalam 
penelitian ini menunjukkan berusia produktif kurang dari 50 tahun. Hasil penelitian menunjukkan bahwa responden paling banyak memiliki pendapatan kurang dari Rp 3 juta per bulan yaitu sebanyak 61 orang atau sebesar 44\%. Hasil ini menunjukkan bahwa responden paling banyak dalam penelitian ini adalah mahasiswa, terlihat dari pendapatan per bulan kurang dari Rp 3 juta. Pendapatan responden ini juga menunjukkan bahwa responden memiliki potensi untuk menjadi wakif dalam produk wakaf uang. Sebanyak 89 orang responden atau sebesar $64 \%$ memiliki jumlah keluarga antara 3 sampai 5 orang. Sebanyak 27 orang responden atau sebesar 20\% memiliki jumlah keluarga kurang dari 3 orang. Responden dalam penelitian ini ada yang memiliki jumlah keluarga lebih dari 5 orang yaitu sebanyak 22 orang responden atau sebesar $16 \%$. Mayoritas responden dalam penelitian ini memiliki anggota keluarga yang sudah bekerja kurang dari 2 orang yaitu sebanyak 81 orang atau sebesar $59 \%$. Anggota keluarga responden yang bekerja antara 2 sampai 4 orang dimiliki oleh 50 orang atau sebesar $36 \%$ responden dalam penelitian ini. Responden yang memiliki anggota keluarga yang bekerja lebih dari 4 orang yaitu sebanyak 7 orang responden atau sebesar $5 \%$.

Responden dalam penelitian ini paling banyak menanggung 1 orang anggota keluarga yaitu sebanyak 76 orang atau sebesar 55\%. Sebanyak 44 orang responden atau sebesar $32 \%$ menanggung antara 2 sampai 3 orang anggota keluarga. Responden dalam penelitian ini juga ada yang menanggung anggota keluarga lebih dari 3 orang yaitu sebanyak 18 orang atau sebesar $13 \%$. Hasil penelitian ini menunjukkan bahwa sampel dalam penelitian ini mayoritas merupakan mahasiswa yaitu sebanyak 124 orang atau sebesar 90\%. Responden dalam penelitian ini yang berstatus sebagai dosen hanya sebanyak 14 orang atau sebesar $10 \%$.

Responden dalam penelitian ini paling banyak sedang menjalani pendidikan tingkat S1 atau D4 yaitu sebanyak 74 orang atau sebesar 54\%. Responden yang sedang jalani pendidikan tingkat pascasarjana (S2 dan S3) adalah sebanyak 62 orang atau sebesar $45 \%$. Responden dalam penelitian ini juga ada yang berasal dari mahasiswa di tingkat diploma (D1-D3) yaitu sebanyak 2 orang atau sebesar $1 \%$.

Hasil penelitian ini menunjukkan bahwa mayoritas responden dalam penelitian ini pernah mendengar atau mengetahui istilah wakaf sebelum membaca kuesioner penelitian ini yaitu sebanyak 135 orang atau sebesar 98\%. Hanya sebanyak 3 orang atau sebesar $2 \%$ yang belum pernah mendengar atau mengetahui istilah wakaf sebelum membaca kuesioner penelitian ini. Responden yang belum mendengar atau mengetahui istilah wakaf uang sebelum membaca kuesioner dalam penelitian ini sebanyak 34 orang atau sebesar $25 \%$.

Sebanyak 96 orang atau sebesar $70 \%$ belum pernah melakukan wakaf uang, sementara sebanyak 42 orang atau sebesar $30 \%$ sudah pernah melakukan wakaf uang. Hasil ini juga menunjukkan bahwa dari sekian banyak responden yang sudah mendengar mengenai wakaf maupun wakaf uang, namun hanya sebanyak 42 orang yang sudah pernah melakukan wakaf uang.

Responden dalam penelitian ini mengetahui tentang wakaf uang paling banyak dari tokoh agama yaitu sebanyak 46 orang atau sebesar 33\%. Sebanyak 28 orang atau 
sebesar 20\% responden dalam penelitian ini mengetahui wakaf uang dari kerabat/orang lain. Responden yang mengetahui wakaf uang dari internet juga cukup banyak yaitu sebanyak 25 orang atau sebesar 18\%. Sebanyak 19 orang atau sebesar 14\% responden mengetahui wakaf uang dari lembaga terkait. Media sosial juga menjadi sumber informasi responden untuk mengetahui wakaf uang, sebanyak 14 orang responden atau sebesar $10 \%$ mengetahui wakaf uang dari media sosial. Responden yang mengetahui wakaf uang dari media TV hanya 5 orang atau sebesar $4 \%$. Hanya sebanyak 1 orang atau $1 \%$ responden yang mengetahui wakaf uang dari surat kabar. Hasil ini menunjukkan bahwa tokoh agama memiliki peran yang penting dalam mensosialisasikan wakaf khususnya wakaf uang kepada masyarakat.

Jumlah responden yang terlibat pada salah satu organisasi sosial keagamaan yang ada adalah sebanyak 58 orang atau sebesar 42\%. Hasil ini menunjukkan bahwa responden dalam penelitian ini yang terlibat pada organisasi sosial keagamaan dengan yang tidak terlibat tidak jauh berbeda jumlahnya. Responden dalam penelitian paling banyak kurang aktif mengikuti kegiatan organisasi yaitu sebanyak 77 orang atau sebesar $56 \%$. Sementara jumlah responden yang aktif mengikuti kegiatan organisasi adalah sebanyak 61 orang atau sebesar 44\% dari 138 responden yang menjadi sampel dalam penelitian ini.

Paling banyak responden akan melakukan wakaf mesjid yaitu sebanyak 51 orang atau sebesar 37\%. Responden yang memilih wakaf uang juga cukup banyak yaitu sebanyak 41 orang atau sebesar 30\%. Wakaf sarana pendidikan juga banyak diminati oleh responden yaitu sebanyak 33 orang atau sebesar $24 \%$. Responden juga ada memilih jenis wakaf lainnya yaitu sebanyak 10 orang atau sebesar $7 \%$.

Data-data dalam penelitian diolah menggunakan software SPSS untuk analisis regresi logistik. Tahap pertama dari analisis regresi logistik adalah uji model fit.

Tabel 1. Hasil Uji Model Fit

Model Summary

\begin{tabular}{|l|l|l|l|}
\hline Step & \multicolumn{1}{|c|}{$\begin{array}{c}-2 \text { Log } \\
\text { likelihood }\end{array}$} & $\begin{array}{c}\text { Cox \& Snell R } \\
\text { Square }\end{array}$ & $\begin{array}{l}\text { Nagelkerke R } \\
\text { Square }\end{array}$ \\
\hline 1 & $157.533^{\mathrm{a}}$ & .084 & .118 \\
2 & $151.224^{\mathrm{b}}$ & .125 & 176 \\
\hline
\end{tabular}

Nilai Cox \& Snell R Square dan Nagelkerke R Square digunakan untuk menilai model fit. Hasil output SPSS pada tabel 1 diatas menunjukkan nilai Cox \& Snell R Square 0,125 dan nilai Nagelkerke R Square sebesar 0,176. Hasil ini berarti variabilitas variabel dependen yaitu yang pernah berwakaf uang dan belum pernah berwakaf uang dapat dijelaskan oleh variabilitas variabel independen (Iman, Didik, Pendapatan, Tanggungan, Norma, Akses media informasi, Organisasi, Usia, dan Pemahaman) sebesar $17,6 \%$.

Model fit juga diuji dengan Hosmer and Lemeshow's Goodness of fit yang menguji hipotesis nol bahwa data empiris cocok atau sesuai dengan model. Jika nilai HosmerLemeshow signifikan atau lebih kecil dari 0.05 maka hipotesis nol ditolak dan model dikatakan tidak fit. Sebaliknya jika tidak signifikan maka hipotesis nol tidak dapat 
ditolak yang berarti data empiris sama dengan model atau model dikatakan fit. (Ghozali, 2009).

Tabel 2. Nilai Hosmer and Lemeshow's Goodness of Fit Hosmer and Lemeshow Test

\begin{tabular}{|c|c|c|c|}
\hline Step & Chi-square & $\mathrm{df}$ & Sig. \\
\hline 1 & 2.464 & 3 & 482 \\
\hline 2 & 5.215 & 7 & .634 \\
\hline
\end{tabular}

Sumber : Hasil Olahan Data Kuesioner

Tabel 2 diatas menunjukkan nilai signifikansi dari nilai Hosmer and Lemeshow test adalah sebesar 0,634, lebih besar dari 0,05. Hasil penelitian tersebut menunjukkan bahwa model regresi logistik penelitian ini sudah merupakan model yang fit.

Tabel 3 Classification Table

Classification Table ${ }^{\mathrm{a}}$

\begin{tabular}{|c|c|c|c|c|}
\hline & \multirow[t]{3}{*}{ Observed } & \multicolumn{3}{|c|}{ Predicted } \\
\hline & & \multicolumn{2}{|c|}{ Persepsi } & \multirow{2}{*}{$\begin{array}{c}\text { Percentage } \\
\text { Correct }\end{array}$} \\
\hline & & .00 & 1.00 & \\
\hline \multirow[t]{3}{*}{ Step 1} & $\begin{array}{ll}\text { Persepsi } & .00\end{array}$ & 93 & 3 & 96.9 \\
\hline & 1.00 & 37 & 5 & 11.9 \\
\hline & Overall Percentage & & & 71.0 \\
\hline \multirow[t]{3}{*}{ Step 2} & $\begin{array}{ll}\text { Persepsi } & .00\end{array}$ & 85 & 11 & 88.5 \\
\hline & 1.00 & 31 & 11 & 26.2 \\
\hline & Overall Percentage & & & 69.6 \\
\hline
\end{tabular}

a. The cut value is .500

Sumber : Hasil Olahan Data Kuesioner

Tabel 3 diatas menunjukkan nilai estimasi yang benar (correct) dan salah (incorrect). Berdasarkan data pada Step 2, prediksi masyarakat yang belum pernah berwakaf uang (kode 0 ) adalah 96 orang, sedangkan hasil observasi hanya 85 orang jadi ketepatan klasifikasi 88,5\% (85/96). Sedangkan prediksi masyarakat yang pernah berwakaf uang (kode 1 ) adalah 42 orang, sedangkan hasil observasi hanya 11 orang jadi ketepatan klasifikasi 26,2\% (11/42) atau secara keseluruhan ketepatan klasifikasi adalah $69,6 \%$.

\section{Tabel 4. Nilai Estimasi Parameter}

Variables in the Equation

\begin{tabular}{|c|c|c|c|c|c|c|c|c|c|}
\hline & \multirow[b]{2}{*}{ B } & \multirow[b]{2}{*}{ S.E. } & \multirow[b]{2}{*}{ Wald } & \multirow[b]{2}{*}{$\mathrm{df}$} & \multirow[b]{2}{*}{ Sig. } & \multirow[b]{2}{*}{$\operatorname{Exp}(B)$} & \multicolumn{2}{|c|}{ 95\% C.I.for $\operatorname{EXP}(B)$} \\
\hline & & & & & & & & Lower & Upper \\
\hline Step $1^{\mathrm{a}}$ & Usia & .603 & 181 & 11.055 & 1 & .001 & 1.828 & 1.281 & 2.607 \\
\hline Step $2^{\mathrm{b}}$ & $\begin{array}{l}\text { Constant } \\
\text { Iman }\end{array}$ & $\begin{array}{l}2.430 \\
.187\end{array}$ & .536 & $\begin{array}{l}20.521 \\
5.905\end{array}$ & $\mid \begin{array}{l}1 \\
1\end{array}$ & $\begin{array}{l}.000 \\
.015\end{array}$ & $\begin{array}{l}.088 \\
1.206\end{array}$ & 1.037 & 1.402 \\
\hline & Usia & 470 & .190 & 6.091 & 1 & .014 & 1.600 & 1.102 & 2.324 \\
\hline & Constant & 6.708 & 1.890 & 12.602 & 1 & .000 & .001 & & \\
\hline
\end{tabular}

Sumber : Olahan Data Kuesioner 
Estimasi parameter dari hasil penelitian ini terlihat pada tabel 4 di atas. Pada step 2 terdapat dua variabel independen yang signifikan yaitu Iman dan Usia. Persamaan regresi logistik dapat dituliskan sebagai berikut :

Atau

$$
\operatorname{Ln}(P /(1-P)=-6,708+0,178 \operatorname{Iman}+0,470 \text { Usia }
$$

$$
\begin{aligned}
\mathrm{P} /(1-\mathrm{P}) & =\mathrm{e}^{-6,708+0,178 \operatorname{Iman}+0,470 \text { Usia }} \\
& =\mathrm{e}^{-6,708} \times \mathrm{e}^{0,178 \operatorname{Iman}} \times \mathrm{e}^{0,470 \text { Usia }}
\end{aligned}
$$

Variabel Iman dan Usia signifikan pada 0,05. Dari persamaan regresi logistik di atas dapat dilihat bahwa log odds masyarakat atau responden yang pernah berwakaf uang secara positif dipengaruhi oleh Iman dan Usia. Jika Usia dianggap konstan, maka odds yang pernah berwakaf uang dengan faktor $\left(\mathrm{e}^{0,178}\right)$ untuk setiap kenaikan Iman. Begitu juga dengan variabel Usia jika Iman dianggap konstan, maka odds masyarakat yang pernah berwakaf uang dengan faktor $\left(\mathrm{e}^{0,470}\right)$ untuk setiap pertambahan usia.

Interpretasi dapat juga dilakukan dengan menyatakan bahwa semakin tinggi iman dan semakin tua usia seseorang, maka probabilitas masyarakat untuk berwakaf uang juga semakin tinggi.

Hasil penelitian ini menunjukkan bahwa karakteristik responden dari jenis kelamin kebanyakan yang menjadi responden adalah perempuan. Karakteristik berdasarkan usia, maka usia responden paling banyak responden berusia antara 20 tahun sampai kurang dari 25 tahun. Tingkat pendapatan responden dalam penelitian ini menunjukkan bahwa responden paling banyak memiliki pendapatan kurang dari Rp 3 juta per bulan. Karakteristik responden berdasarkan status pernikahan, mayoritas responden dalam penelitian ini belum menikah. Responden dalam penelitian ini kebanyakan memiliki anggota keluarga antara 3 sampai 5 orang. Jumlah anggota keluarga antara 3 - 5 orang tersebut, kurang dari 2 orang yang bekerja. Karakteristik ini paling banyak dimiliki oleh responden dalam penelitian ini. Responden dalam penelitian ini walaupun lebih banyak berstatus belum menikah, namun memiliki tanggungan keluarga yaitu menanggung 1 orang di keluarga responden. Kondisi ini juga paling banyak dimiliki oleh responden dalam penelitian ini. Responden dalam penelitian ini mayoritas adalah mahasiswa yang sedang kuliah di tingkat Sarjana. Kebanyakan responden dalam penelitian ini belum bekerja hanya sebagai mahasiswa. Responden dalam penelitian ini mayoritas mahasiswa dari Perguruan Tinggi Swasta. Wilayah aktivitas responden dalam penelitian ini kebanyakan berada di Jakarta Pusat.

Hasil penelitian yang menunjukkan karakteristik responden ini berkaitan dengan jumlah responden yang sudah melakukan wakaf uang dengan yang belum melakukan wakaf uang. Responden dalam penelitian ini mayoritas belum pernah melakukan wakaf uang yaitu sebanyak 96 orang, sisanya sebanyak 42 orang sudah pernah melakukan wakaf uang.

Rendahnya jumlah responden dalam melakukan wakaf uang ini sesuai dengan hasil penelitian yang dilakukan Fanani (2011), Furqon (2011), Nizar (2014), Abdullah dan Aristoni (2015), Mochtar, Sidin and Razak (2015), dan Dahlan (2017). Penelitianpenelitian sebelumnya menunjukkan tingkat partisipasi masyarakat dalam berwakaf 
khususnya wakaf uang yang masih rendah, sehingga dasar tersebut menjadi dasar melakukan penelitian mengenai wakaf uang.

Hasil penelitian ini setelah dilakukan analisa regresli logistik menunjukkan bahwa variabel tingkat keimanan seseorang dan usia seseorang dapat mempengaruhi persepsi untuk melakukan wakaf uang secara signifikan. Penelitian ini berbeda dengan hasil penelitian yang dilakukan oleh Nizar (2014). Hasil penelitian Nizar (2014) menunjukkan bahwa variabel pendidikan memiliki peluang yang lebih besar dan signifikan dalam menjelaskan persepsi wakif tentang wakaf uang.Terkait keimanan dan usia terkadang sejalan dalam kehidupan ini, seiring dengan bertambahnya usia tentu akan semakin kuat keimanan sesorang atau sebaliknya.

\section{PENUTUP}

Kesimpulan hasil penelitian sebagai berikut:

a. Karakteristik responden berdasarkan demografi sosio-ekonomi sivitas akademika muslim menunjukkan bahwa responden dalam penelitian ini merupakan sivitas akademika muslim yang memiliki tingkat sosio-ekonomi menengah dengan jumlah pendapatan kurang dari Rp 3 juta, status bekerja lebih banyak sebagai mahasiswa, memiliki usia antara 20 sampai kurang dari 25 tahun, dan mayoritas memiliki status sebagai mahasiwa.

b. Faktor-faktor yang mempengaruhi persepsi responden dalam melakukan wakaf uang berdasarkan hasil analisa regresi logistik hanya faktor Iman dan Usia. Semakin tinggi tingkat iman seseorang dan semakin tua usia seseorang, maka semakin tinggi untuk melakukan wakaf uang. Saran yang bisa ditawarkan dari hasil penelitian ini, adalah:

a. Para pemangku kepentingan wakaf khususnya wakaf uang di Indonesia harus secara rutin melakukan sosialisasi kepada masyarakat mengenai wakaf uang.

b. Tingkat keimanan seseorang dapat meningkat dengan peningkatan kajian di forum-forum pengajian tentang manfaat wakaf uang yang dapat meningkatkan keimanan seseorang.

c. Penelitian selanjutnya dapat menggunakan faktor-faktor lain dalam menentukan tingkat pemahaman masyarakat mengenai wakaf uang selain faktor sosio-ekonomi.

\section{DAFTAR PUSTAKA}

Abdullah, Junaidi dan Aristoni. 2015 Wakaf Uang Sebagai Instrumen Sistem Ekonomi Islam Yang Berkeadilan, Jurnal ZISWAF, Vol. 2, No. 1, Juni 2015

Badan Wakaf Indonesia, 2016, Laporan Nazhir Pengelola Uang

Cizakca, Murat Cizakca, 2004, Ottoman Cash Waqfs Revisited: The Case of Bursa 1555. 1823, UK: FSTC, 2004, hal. 1.

Dahlan R. 2014. Faktor-faktor yang memengaruhi persepsi nazhir terhadap wakaf uang. Jurnal Al-Iqtishad: Vol. VI No. 2, Juli 2014

Dahlan, Rahmat. 2017 Faktor-Faktor Yang Mempengaruhi Persepsi Nazhir Terhadap Wakaf Uang, Jurnal Zakat dan Wakaf, ZISWAF, Vol. 4, No. 1, Juni 2017 
Daniel Crecelius 1995, "Introduction," Journal of the Economic and Social History of the Orient, Leiden:E.J.Brill, v.38, part 3 (august), 1995,

Handayani, T. Kurnia,2015. Analisis Persepsi Masyarakat Kota Bogor Terhadap

Wakaf Tunai Bogor People Perception Analysis To The Cash Waqf, Jurnal Syarikah Volume 1 Nomor 2, Desember 2015

Hasanah U. 2009. Wakaf Produktif untuk Kesejahteraan Sosial dalam Perspektif Hukum Islam di Indonesia [Internet]. [diunduh 31 Januari 2017]

Nasution M E dan Hasanah. 2005. Wakaf Tunai Inovasi Finansial Islam, Peluang dan Tantangan dalam Mewujudkan Kesejahteraan Umat. Jakarta (ID): PKTTI-UI.

Nizar A. 2014. Faktor-faktor yang memengaruhi persepsi wakif tentang wakaf uang. Jurnal Bisnis dan Manajemen Vol 4, No 1. 2014

Mokhtar, Mohd Farhanah, Emira Mad Sidin, Dzuljastri Abd. Razak. 2015. Operation of Cash Wakaf and it's Limitation, Journal Of Islamic Economics, Banking and Finance, Vol 11, No4, oct-Dec 2015

Rahmawati, Yuke .2013. Persepsi Wâqif dalam Berwakaf Tunai, Jurnal Al-Iqtishad: Vol. V, No. 1, Januari 2013

Sarwono, Sarlito W . 2010. Pengantar Psikologi Umum. Jakarta: Rajawali Pers

Slameto (2010), Belajar dan Faktor dan Faktor yang Mempengaruhinya, Jakarta, Rineka Cipta.

Walgito. Bimo, 2010. Pengantar Psikolog Umum. Yogyakarta: C.V Andi Offset 